\title{
BIOLOGICAL CONTROL OF TOMATO PESTS IN EGYPT
}

\author{
MESBAH, A. H. ${ }^{1}$, M. ELSAADANI ${ }^{2}$, H. ASHOSH ${ }^{3}$, \\ E.E. HAFEZ ${ }^{2}$ and A. E. GAZELLE ${ }^{2}$ \\ 1 Plant Protection Research Institute, Department of Biological Control, ARC, Giza, \\ Egypt. \\ 2 Mubarak City for Scientific Research and Technology application. \\ 3 Field Crops Res, Institute, Agric. Res. Center, Egypt
}

(Manuscript received 23 February 2011)

\begin{abstract}
Biological control trial on tomato plants were carried out at Mubarak City for Scientific Research and Technology Application, New Borg El-Arab, Alexandria, Egypt during two tomato summer seasons; 2008 and 2009 compared with field treated with insecticides. The most serious insect pests in both fields were Heliothis armigra, Spodoptera littoralis and S. exigua larvae. The pests control in the biological field depended mainly on releasing of the coccinellid species and the parasitoid Trichogramma evanescens. The releases were timed according to the catches of the pheromone traps and the weekly survey of the insect pests. The pests, control in the traditional field depended only on insecticide treatments. In 2008 season in the biological control field, five releases of mixture of coccinellid predators; Coccinella undecimpunctata, C. sptempunctata and Hypodimia trideampunctata at ratio of to $17: 7: 5$, respectively. In the second season, six releases of $C$. undecimpunctata and one of parasitoid, Trichogramma evanescens were done in biological control field. In the corresponding insecticide treatment field, four insecticide applications were carried out in the first season 2008 , while in the second season, three insecticide treatments were applied. The infestation rates in the first season in tomato fruits were 1.3 and $3.8 \%$ in biological control and insecticide treated fields, respectively. While in the second season, these rates were 0.2 and $2.7 \%$ in the two fields, respectively. The tomato production was estimated with 9174 and $3867 \mathrm{~kg} / \mathrm{fed}$. in biological control and insecticides treated field in 2008 season, respectively, while in the second season those were 5804 and $3812 \mathrm{~kg} /$ fed., respectively.

Key words: Tomato production, biological Control, Predators, Heliothis armigra.
\end{abstract}

\section{INTRODUCTION}

Tomato is one of the most important vegetable crops, but its production is usually subject to high risk in the markets because of drastic changes in the prices. Also, the crop suffers from infestations of insect pests and infections of diseases. Because tomato is a cash crop with usually a high value, the growers tend to use 
insecticides and fungicides indiscriminately to ensure high productivity and reasonable benefits.

Pesticides are known as toxic compounds to human-beings as well as to many other non-target organisms (Poster, 1987). Non-biodegradable pesticides cause contaminate soil, water system and food chains, and constitute a major components of environmental pollution, so the chemical control has become a troubled pest management strategy (Debach and Rosen, 1991).

Since several years ago, because of limited cultivated area in Egypt, the policy of Ministry of Agriculture in has emphasized crop intensification. For this reason, heavy duties are added to responsibilities of agriculturists, especially the plant protection specialists. Thus, the difficult equation has become how to increase crop production with less, or without, pesticides. The strategy of integrated pest management (IPM) could be the solution if taken seriously. Among the means of IPM, is understanding the role of natural enemies in different agricultural ecosystems to preserve and encourage their presence and use in suppressing pest population (Tawfik and El-Husseini, 2002). To apply IPM systems, there is a need to have good knowledge on the biology and ecology of the target insect pests and associated natural enemies as well as the climatic conditions. Decisions of pest control should be based upon survey of the pests and their associated natural enemies, with limited applying of insecticides if needed (Mesbah, 2007).

The current investigation was undertaken at the experimental farm of Arid Lands Cultivation and Development Research Institute, Mubarak City for Scientific Research \& Technology Applications to produce tomato without insecticide in order to produce healthy uncontaminated tomato fruits and to keep this new area away from pesticide pollutions.

\section{MATERIALS AND METHODS}

A field experiment was carried out at Mubarak City for Scientific Research and Technology Application, New Borg El-Arab City, Alexandria Governorate during two successive summer seasons; (2008 and 2009).

Tomato seedlings were sown on April $1^{\text {st }}$ in 2008 season and on March $15^{\text {th }}$ in 2009. The experimental field was divided into area "A" of a quarter feddan (biological control field), area "B" (traditional field) of another quarter feddan, treated with insecticides against tomato insect pests during the two experimental seasons. In the first season (2008) five predator releases were done in the biological control field on April $15^{\text {th }}$, April $26^{\text {th }}$, May $10^{\text {th }}$, June $17^{\text {th }}$ and June $23^{\text {rd }}$. The predator adults were 
Coccinella undecimpunctata, C. septempunctata and Hypodimia trideampunctata at ratio of 17: 7: 5 , respectively. The numbers of released predators in the five dates were 320, 272, 384, 448 and 352 predators, respectively. These predators were collected from the weeds (Mesbah and El-Husseini, 2009). In the second season (2009), six releases of C. undecimpunctata were carried out on April $24^{\text {th }}$, May $19^{\text {th }}$, May $24^{\text {th }}$, June $5^{\text {th }}$, June $10^{\text {th }}$ and June $27^{\text {th }}$ with rates, $480,160,200,440,600$ and 480 predators/fed., respectively. In addition, the parasitoid, Trichogramma evanescens was released on June $14^{\text {th }}$ at a rate of 120 thousand wasps/fed. In the second season $C$. undecimpunctata was mass-reared under laboratory conditions on aphids. As for the insecticide treated field, four insecticide applications were carried out in 2008 season; profenofos (Selecron 72\% EC), malathion (Malathion 57\%) and chlorfluazuron (Atabaron 5\% EC) + chlorpyrifos (Bestban 48\% EC) two times. In the second season (2009), three insecticide treatments were carried out; selecron, malathion, chlorpyrifos + chlorfluazuron, respectively.

Pheromone traps:

For monitoring Spodotpera littoralis adults in the first and second seasons and Heliothis armigera male moths, baited water pheromone traps were used. The number of moths were recorded every three nights, while the pheromone was replaced every 10 days.

Mean of adult counts between different treatments were compared using "t" test.

\section{RESULTS AND DISCUSSION}

In the biological control field, the predatory releases were carried out on basis of weekly surveying of tomato insect pests and pheromone trap catches.

\section{Major insect pests of tomatoes:}

Field examination of the tomato experimental field revealed that the major insect pests were $H$. armigera, Spodoptera littoralis and $S$. exigua larvae, in addition to jassids, Bemisia tabaci and aphids. The most of damage was caused by lepidopterous larvae especially in the first season, larvae fed on buds and flowers of tomato plants and may also bore into the stem and preferred the fruits. Generally, the period from the third week of June until the first week of July witnessed the serious lipedopterus larval infestation. In the first season (2008) in the biological control field, Spodoptera moths increased suddenly on June 17 (64 moths/3 nights) (Fig. 1) and reached the highest numbers on June 23 ( 86 moths/3 nights). Meanwhile, the highest infestation rate of tomato fruits was recorded in the third week of June (27.2\%), 
followed by $6.8 \%$ in the fourth week of June (Table 1 ). The infestation declined during July and reached to $0.3 \%$ in the third week of July. The overall mean of the infestation rate during 2008 season was $1.3 \%$. Five releases of coccinellid predators were carried out during 2008 season in biological control field. In the insecticide treated field, the highest infestation in tomato fruits were recorded in the third week of June and in the second one of July, (6.5 and $5.2 \%$, respectively), while the lowest rate of infestation (1.2\%) occurred in the third week of July (Table 1 ). The overall mean of the infestation of tomato fruits in the first season in insecticide treated field was $3.8 \%$. In the second season (2009), generally, no infestation was recorded with Heliothis armigra larvae, while only one moth of Heliothis was recorded throughout the whole season. In the biological control field, in spite of appearance of Spodoptera moths early in the pheromone trap (on April 24 with a rate, 18 moths/3 nights) (Fig. 2), no infestation was recorded until the third week of June (Table 1). The lowest infestation was recorded during the first and second weeks of July. The overall mean of infestation during 2009 in the biological control field was $0.2 \%$. During this season, six releases of $C$. undecimpunctata and only one release of the parasitoid, Trichogramma evanescens was done in the biological control field. In the insecticide treated field, the highest infestation of tomato fruits occurred in the fourth week of June $(6.1 \%)$ followed by $2.4 \%$ in the second week of July, while the lowest infestation was recorded in the third week of July $(0.5 \%$ (Table 1$)$. The overall mean of infestation was $2.7 \%$. In this season, three insecticide treatments were applied. The present results are in agreement with those of Neeson 2004 who found the Heliothis punctigra and $H$. armigera were the most common insect pests that damage tomatoes. One key to a successful organic greenhouse operation is maintaining rigorous pests management (Dodson et al., 2002). The present data also revealed that in spite of the increasing of Spodoptera male moths numbers in the pheromone traps late in the season, there was low infestation in tomato fruits. Similar finding was recorded by Mesbah (2007) who found that in late cotton season, the male moths of Spodoptera littoralis were attracted to the pheromone traps, while the females laid their eggs on nearby suitable crops. The differences between insects infestation in biological control field and insecticide-treated field were insignificant in 2008 season ( $t$ $=0.906)$, while they were highly significant in the second season $(t=27.75)$ (Table 1). 
Table 1. Weekly production of tomato fruits and their infestation rates with lepidopterous worms in the biological control and insecticide treated fields.

\begin{tabular}{|c|c|c|c|c|c|c|c|c|}
\hline \multirow{3}{*}{ Date (weekly) } & \multicolumn{4}{|c|}{2008 season } & \multicolumn{4}{|c|}{2009 season } \\
\hline & \multicolumn{2}{|c|}{ Fruits production $\mathrm{kg} / \mathrm{fed}$. } & \multicolumn{2}{|c|}{$\begin{array}{l}\text { Infested } \\
\text { fruits \% }\end{array}$} & \multicolumn{2}{|c|}{$\begin{array}{l}\text { Fruits production } \\
\qquad \mathrm{kg} / \mathrm{fed} .\end{array}$} & \multicolumn{2}{|c|}{$\begin{array}{l}\text { Infested } \\
\text { fruits \% }\end{array}$} \\
\hline & B & I & B & I & B & I & B & I \\
\hline \multicolumn{9}{|l|}{ June } \\
\hline $2^{\text {nd }}$ week & 0 & 0 & 0 & 0 & 96 & 0 & 0 & 0 \\
\hline $3^{\text {rd }}$ week & 18 & 22 & 27.2 & 6.5 & 432 & 140 & 0 & 0.7 \\
\hline $4^{\text {th }}$ week & 764 & 150 & 6.8 & 1.7 & 1032 & 132 & 0.4 & 6.1 \\
\hline \multicolumn{9}{|l|}{ July } \\
\hline $1^{\text {st }}$ week & 1710 & 511 & 2.1 & 1.6 & 2048 & 1001 & 0.1 & 2.0 \\
\hline $2^{\text {nd }}$ week & 1380 & 1737 & 0.6 & 5.2 & 1716 & 1812 & 0.1 & 2.4 \\
\hline $3^{\text {rd }}$ week & 4668 & 1369 & 0.3 & 1.2 & 480 & 728 & 0 & 0.5 \\
\hline $4^{\text {th }}$ week & 604 & 78 & 0.7 & 1.4 & - & - & - & - \\
\hline Total & 9174 & 3867 & 1.3 & 3.8 & 5804 & 3812 & 0.2 & 2.7 \\
\hline "t" calculated & \multicolumn{2}{|c|}{1.66} & \multicolumn{2}{|c|}{0.906} & \multicolumn{2}{|c|}{1.53} & \multicolumn{2}{|c|}{$27.75^{* *}$} \\
\hline "t" tabulated & \multicolumn{2}{|c|}{2.57} & \multicolumn{2}{|c|}{2.57} & \multicolumn{2}{|c|}{2.57} & \multicolumn{2}{|c|}{2.57} \\
\hline
\end{tabular}

$\mathrm{B}=$ Biological control field.

I. = Insecticide -treated field 


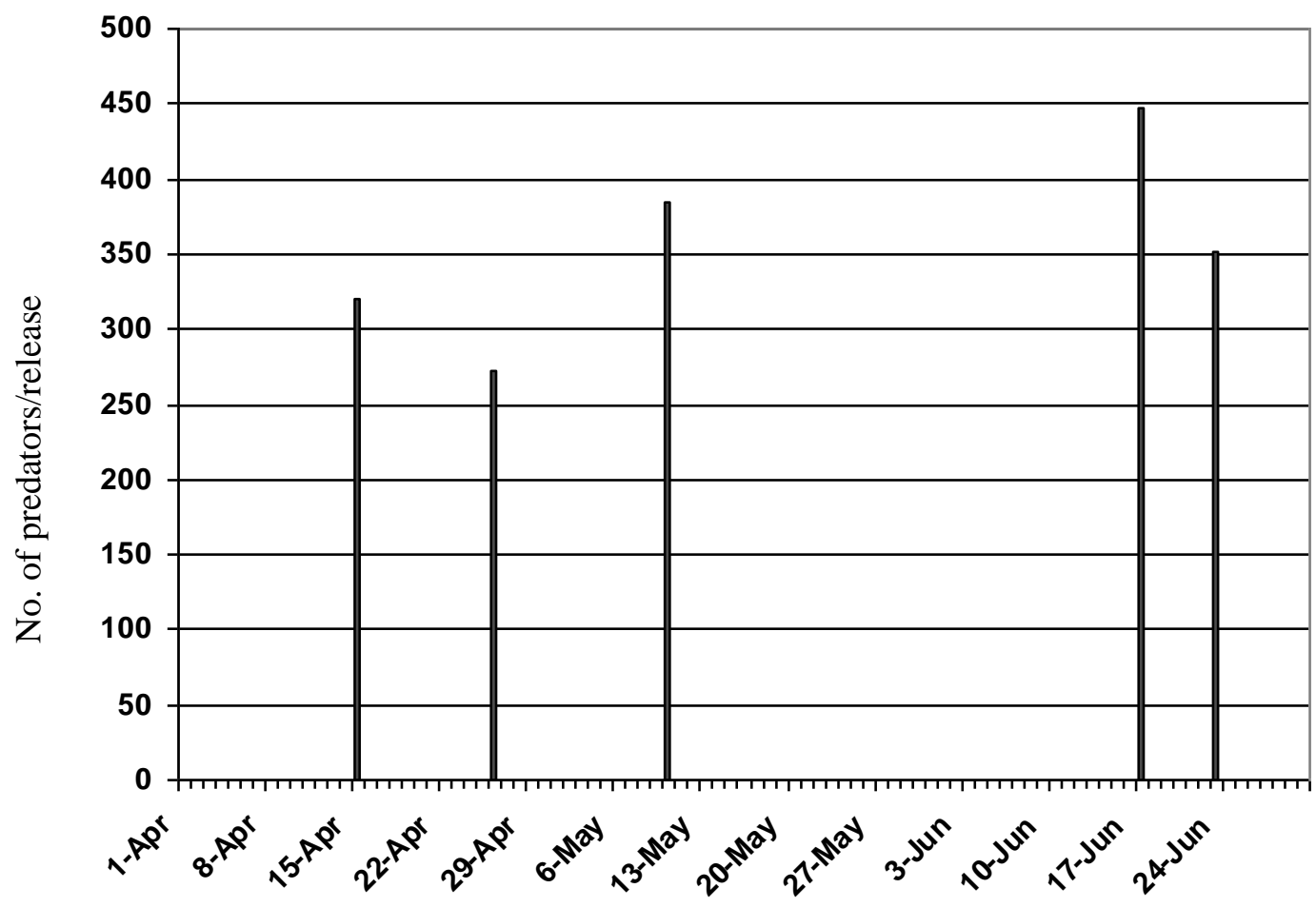

Date of predators release

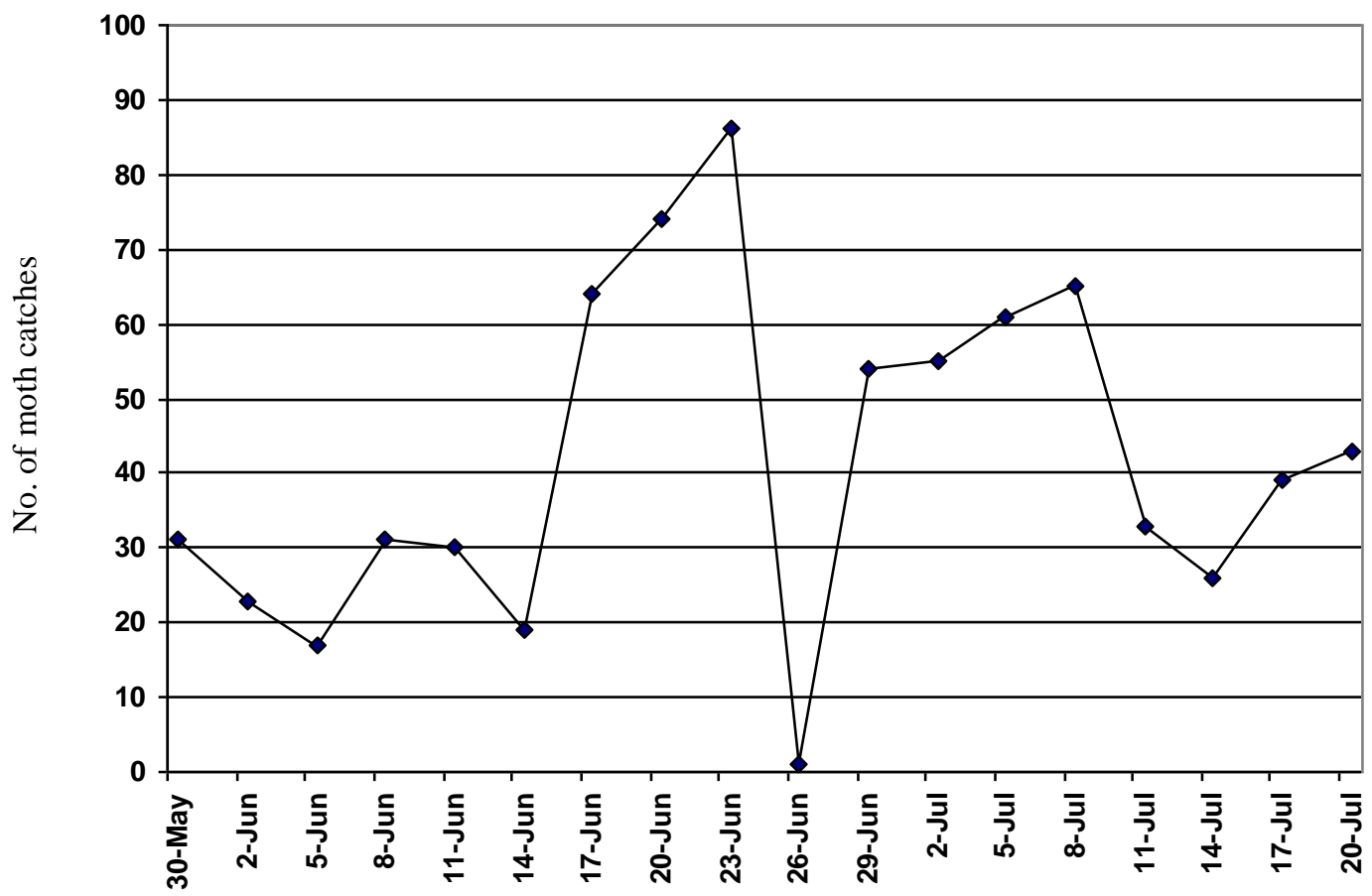

Date of pheromone trap catches

Fig. 1. Predatory releases and pheromone trap catches of Spodoptera littoralis male moths in 2008 season. 


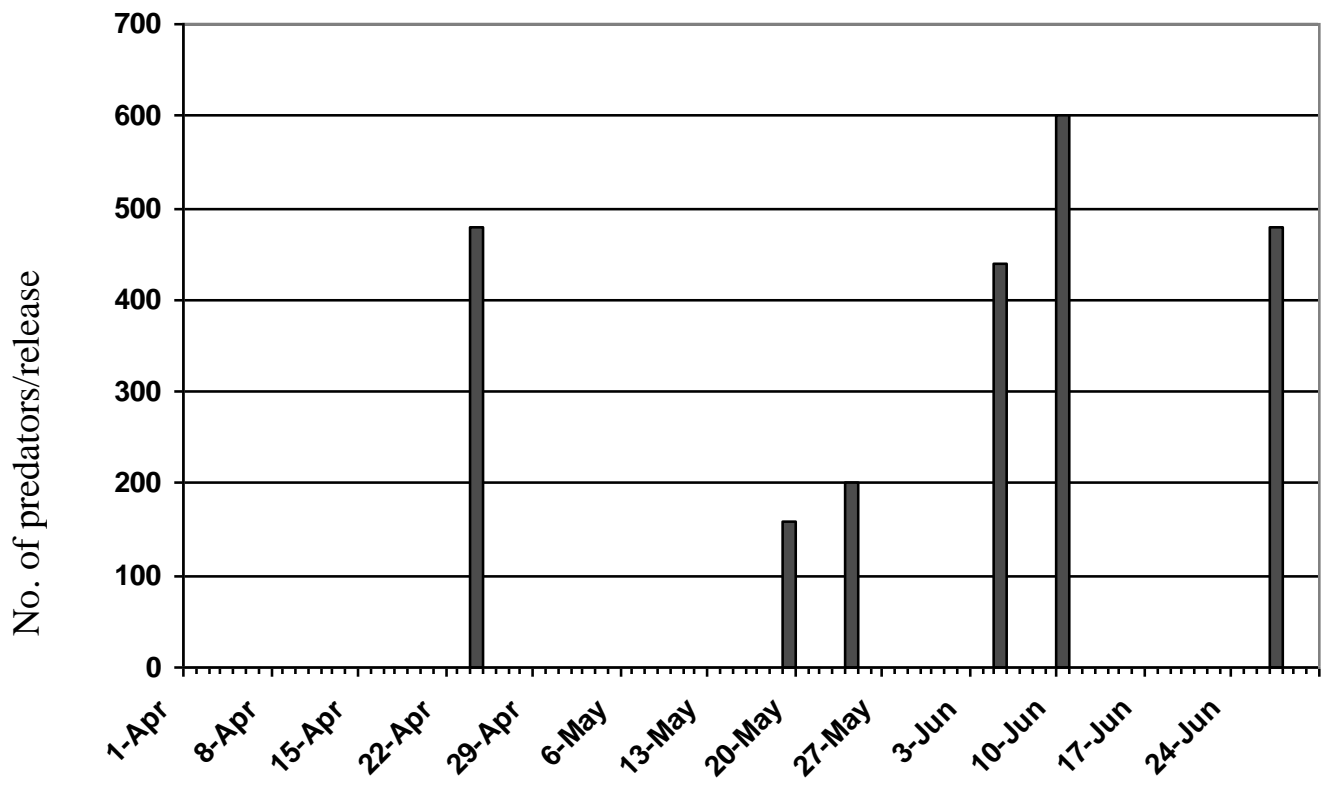

Date of predators release

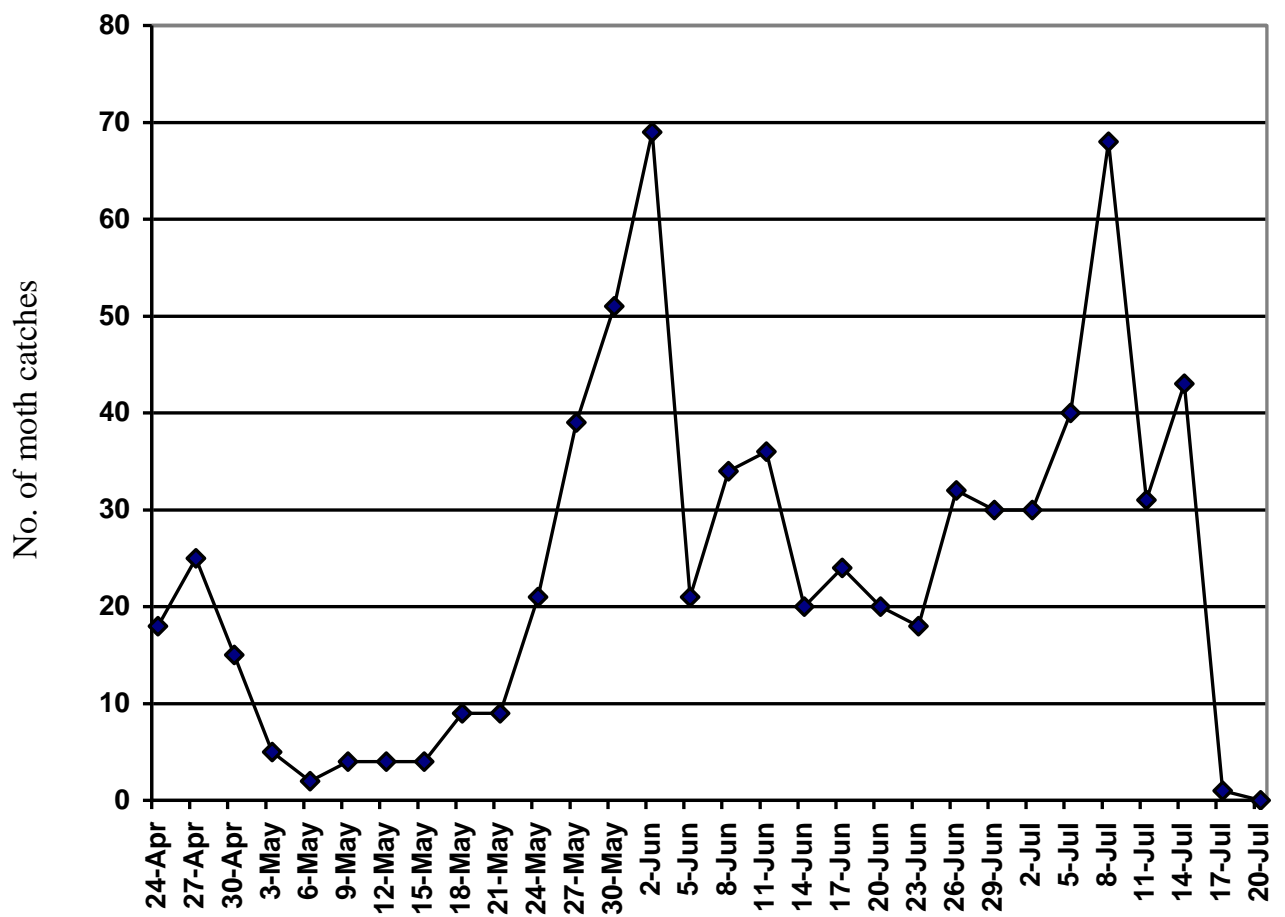

Date of pheromone trap catches

Fig. 2. Predatory releases and pheromone trap catches of Spodoptera littoralis male moths in 2009 season. 


\section{Tomato production:}

Tomato production began in the two fields during the third week of June, 2008, (18 and $22 \mathrm{~kg} /$ fed., respectively, Table 1 ). The period from the third week of June until the third one of July was the real period of tomato production. The highest peaks of production in the biological control field during 2008 season were recorded in the first and third week of July (1740 and $4668 \mathrm{~kg} /$ fed., respectively). In insecticidetreated field, the major production was recorded in the second and third weeks of July, (1737 and $1369 \mathrm{~kg} /$ fed., respectively). The same trend was observed in the results in the second season (Table 1), where the highest production of tomato fruits in the biological control field was recorded from the third week of June $(1032 \mathrm{~kg} / \mathrm{fed}$.) through the second week of July, $2048 \mathrm{~kg} / \mathrm{fed}$. and $1716 \mathrm{~kg} / \mathrm{fed}$. in the first week and the second week, respectively. Meanwhile, in insecticide treated field, they were 1001 and $1812 \mathrm{~kg} / \mathrm{fed}$., in the same period. The total production of tomato fruits in biological control field and insecticide treated one in 2009 seasons were 5804 and $3812 \mathrm{~kg} / \mathrm{fed}$., respectively. It is noteworthy that the harvest period in the second season (2009) was shorter than that of the first season due to cut off irrigation water in the experimental farm for a long time during the harvest period. However, the present results are not in line with those of Steffen et. al. (1995) who indicated that the yield produced under organic system is very similar to that produced by the conventional control. Differences between tomato yield in the biological control field and insecticide-treated one were insignificant in the two seasons 2008 and 2009, where calculated "t" = 1.66 and 1.53 , respectively. It is noteworthy also that in spite of the increasing of tomato production in the biological control field during the two seasons as compared to the insecticide treated one, there was an increase in the infestation rates in insecticide treated field than that in biological control field during the two seasons (Table 1). On the other hand, there an increasing demand for production of insecticidal free products. Such unpolluted commodities are safe and healthy, as well as they could be sold in higher price. Besides, there is high merit in biological control system, where it keeps the environmente far from the pollution.

\section{ACKNOWLEDGEMENT}

The authors express their deep thanks, toProf. Dr. Ramzy Sherif, Chief Researcher and Manager of Regional Research Stations for reviewing valuable comments an the manuscript. Also, thanks to Mr. Rabie H. El-Sayed Hafez, Technician in Mobarak Scientific City for his sincere assistance during the field and laboratory work. 


\section{REFERENCES}

1. Debach, P. and D. Rosen (Eds.) 1991. Biological control by natural enemies. Second edition. 440 pp.

2. Dodson, M., J. Bachmann and P. Williams. 2002. Organic greenhouse tomato production. Appropriate technology transfer for Rural. Arfas. ww.attra.ncat.org. 16 pp.

3. Mesbah, A.H. 2007. Integrated pest management on major cotton insect pests at Kafr El-Sheikh region. Egypt. J. Agric. Res., 85(6): 2027-2050.

4. Mesbah, A.H. and M.M. El-Husseini. 2009. Effect of weed borders on insect pests and their associated predators on sugar beet and cotton plant fields. Egypt. Acad. J. Biolog. Sci., 2(1): 73-80.

5. Neeson, R. 2004. Organic processing tomato production. Agfact H8.3.6. First edition, April, $11 \mathrm{pp}$.

6. Poster, S. 1987. Defusing the toxics threat: Controlling pesticides and industrial waste. world watch paper 79. Washington, D.C: Worldwatch Inst.

7. Steffen, K.L., M.S. Dann, J. K. Harper, S.J. Fleischer, S.S. Mkhize, D.W. Grenoble, A.A. MacNab, K. Fager and J.M. Russo. 1995. Evaluation of the initial season for implementation of four tomato production system. J. Am. Soc. Hortic. Sci. 120(2): p. $148-156$.

8. Tawfik, M.F.S. and M.M. El-Husseini. 2002. Natural enemies of commonly distributed insect pests in Egyptian Agro-ecosystems. Egypt. J. Boil. Pest Control. 12(2): 131-141. 


\section{المكافحة الحيوية لأفات الطماطم فى مصر}

\section{احمد حسن مصباح1 ، محمد السعدنى 2، حسن عشوش3، السيد السيد حافظ2 احمد إسماعيل غزالهة}

$$
\begin{aligned}
& \text { 1- معهد بحوث وقاية النباتات - قسم بحوث المكافحة الحيوية محطة البحوث الزراعية سخا - كفر }
\end{aligned}
$$

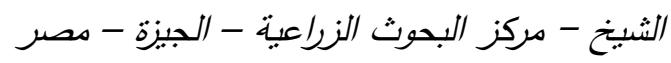

$$
\begin{aligned}
& \text { 2- مدينه مبارك للأبحاث العلدية والتطبيقات التكنولوجية. }
\end{aligned}
$$

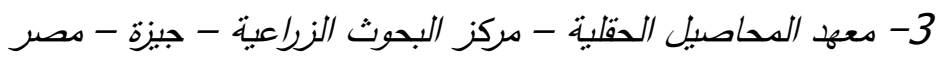

أجريـت هذه التجربـة على نباتـات الطمـاطم في مدينـه مبـارك للأبحـاث العلميـة والتطبيقات

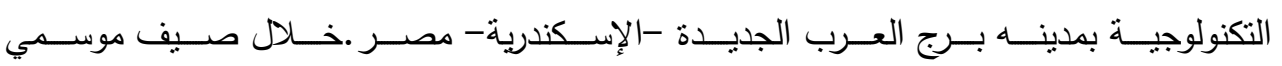
2008و 2009وذلك مقارنة بحقل معامل بالمبيدات. وكانت اخطر الآفات الحشرية في كلا الحقلين المكافحة الحيوية والمعامل بالمبيدات وهيى دودة بلات ثمار الطماطم الأمريكية ودودة ورق القطن الكبرى والصغرى .ولقد أعتدمدت المكافحة في حقل فئل

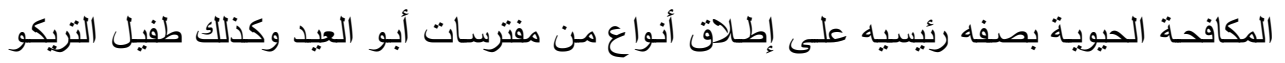

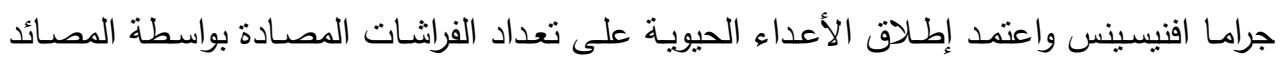
الفرمونيه وكذلك الحصر الاسبوعى للآفات . أما في حقل المكافحة التقليدية بالمبيدات فقد اعتمد على استخدام المبيدات الحشرية فقط.

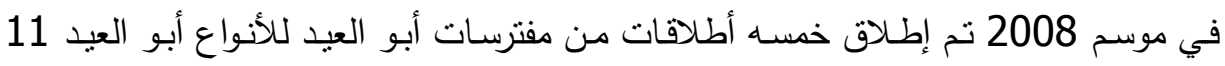
نقطه, أبو العيد 7نقط و أبو العيد 13 نقطه بنسبة 5:7:17 لكل منهم على التوالي وفى الموسم التالي تم إطلاق 6 أطلاقات من المفترس أبو العيد 11 نقطه بالإضـافة إلى إطلاقهـ واحده من إنس

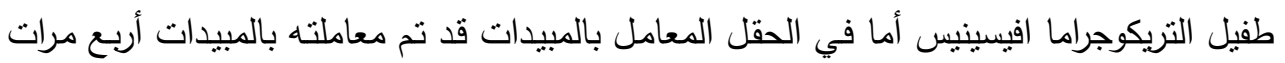

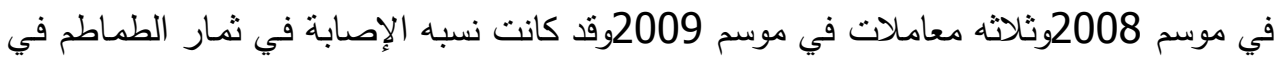

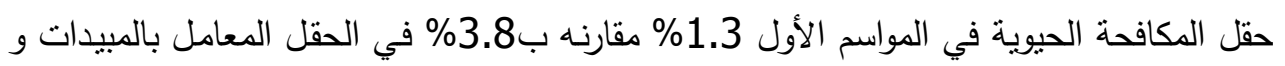
في الموسم الثناني كانت 0.2\% و 2.7\% في حقل المكافحـة الحيويـة والحقل المعامل بالمبيدات على التوالي • وقد كان إنتاج الطماطم في الموسم الأول هو

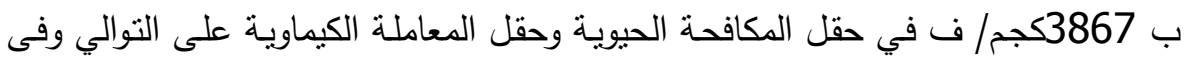

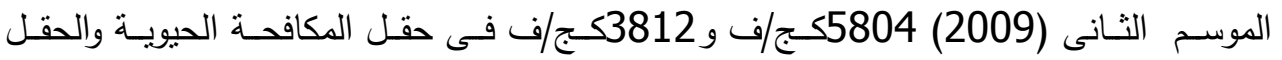

